"Were valuable art works an economic form of money during the German Third Reich Period and its aftermath?"

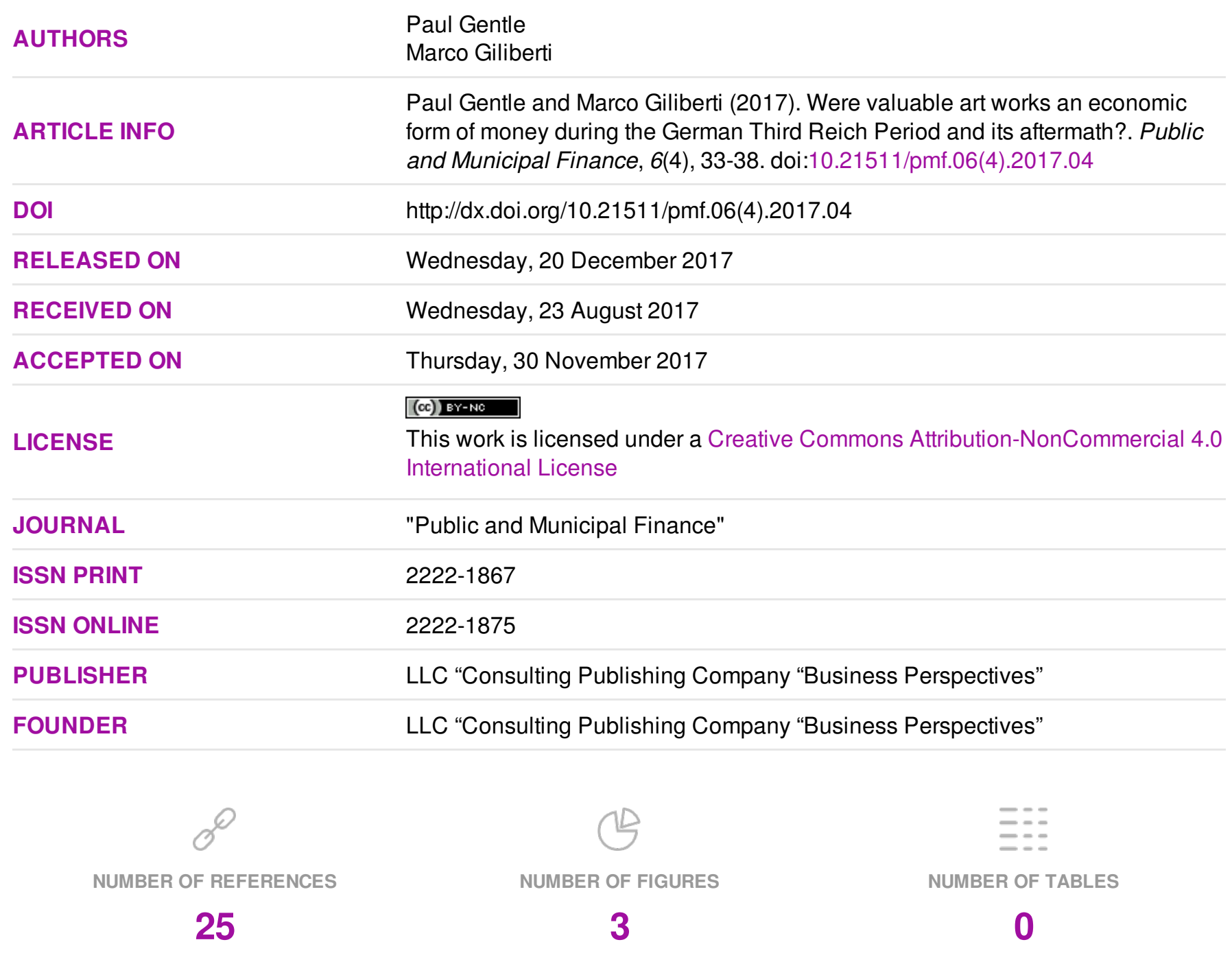

(c) The author(s) 2022. This publication is an open access article. 
Paul Gentle (China), Marco Giliberti (USA)

\title{
Were valuable art works an economic form of money during the German Third Reich Period and its aftermath?
}

\begin{abstract}
This paper examines the special use of art works as a store of value in Germany during the Third Reich era. Some Jews were able to buy their freedom, as the fascists closed in. Then as the Third Reich fell, some escaping fascists used art works to secure freedom outside of Germany. One of the characteristics of money is a store of value. When confidence in a currency is present, the more conventional form of money takes precedence. A respected, economic form of currency and coin has all three elements of money: medium of exchange, store of value and unit of account. This last trait is especially absent when using various art works as money, as there is no agreed upon unit of account with such different art. Furthermore, art works could not qualify as a medium of exchange, since only a very small amount of the population was involved in this way of dealing in art during the stressed times for the Third Reich.
\end{abstract}

Keywords: defining money, Third Reich in Germany in World War II, stolen art, Matisse, El Greco, August Klimt.

JEL Classification: N4, N14.

Received on: $23^{\text {rd }}$ of August, 2017.

Accepted on: $30^{\text {th }}$ of November, 2017.

\section{Introduction}

In a recent article by Paul Harris (2016), the accomplishments of Robert K. Posey are examined. Posey lived in Alabama and New York, during peace time and in both Canada and Europe, during war time ${ }^{1}$. The article by Posey mentioned the great value of many of the stolen works of art. This trait of being a store of value has caused some scholars to wonder how valuable art works can be compared to money. The fact is that money can be thought of "as anything that is generally accepted in payment for goods or services or in the repayment of debts" (Mishkin, 2006). Sometimes money is paper and coins and this is what lay people first think of when they hear the word money. In addition, economists add in deposit accounts and financial instruments, such as bonds (Mishkin, 2006). There are unique situations when something more unfamiliar takes on traits of money, most often in an environment and time when currency and coin and other normal types on money are less available than normal. For instance, cigarettes were used as a medium of exchange in prisoner of war camps in Germany, during the World War II (Radford, 1945). Prior to that, Native American wampum served as money during part of the colonial era in America. This wampum was originally used in art work and as a means of recording histories, treaties and sometimes messages within tribes and between tribes. Once European settlers came to America, the

(C) Paul Gentle, Marco Giliberti, 2017.

Paul Gentle, Visiting Assistant Professor of Business and Economics, NCC British Higher Education GZIT, Guangzhou, China.

Marco Giliberti, Ph.D. Candidate, Agricultural Curriculum and Teaching Education, Auburn University, USA.

This is an Open Access article, distributed under the terms of the Creative Commons Attribution-NonCommercial 4.0 International license, which permits re-use, distribution, and reproduction, provided the materials aren't used for commercial purposes and the original work is properly cited. wampum started being used as money. Black beads of wampum were more valuable than white beads and so we can see the concept of money having a unit of account (Gentle, 2016). It is the medium of exchange trait and store of value trait that made wampum a better means of money than the art work in Germany during the World War II period and postwar period. Within a small group of very rich fascists, the valuable art works were used to buy favor in escaping Germany, after the war. An accepted currency and coin system would satisfy the three traits requirement well. Precious metals such as gold or silver can also satisfy the necessary traits for something being money. The absence of sufficient and satisfactory currency coins caused the above three alternatives to be used until currency and coin could be made available. In the case of cigarettes, medium of exchange and unit of account requirements are satisfied well, provided there are still enough smokers in an economy. The store of value requirement would be less satisfied (Radford, 1945). In the case of North American wampum, all three traits were satisfied. In part of Eastern North America, once Western European settlers came to the area until sometime in the eighteenth century. Wampum was accepted as a medium of exchange, had units of account (black beads and white beads) and some store of value (Gentle, 2016). In the example of famous art works used by Jews and German fascists as a medium of exchange amongst a limited number of people, art works did have a high store of value. Unfortunately, the famous art works did not satisfy the unit of account and medium of exchange requirements. For example, a painting cannot be divided up into units of pennies. Plus, if only a very limited amount of population is using valuable of art works in trading, it is incomparable in a way that USA dollars can be divided into half-dollars, quarters, dimes, nickels and pennies. 
Also, valuable art works certainly do not qualify as a wide spread medium of exchange. Art works were worth very high values and so only a small number of people were involved with this. So the relationships between different people of a certain wealth class and situation, such as being on the run, would account for some of the value of these art works, as they could thus be sold or trade more easily. Perhaps in a way this may be elaborated on in the views of anthropologists, such as Herskovits (1965), in their concern about the relationships of people. Gentle (2016) states that both economics and anthropology can simultaneously add to many discussions of social science topics.

\section{Value}

The concept of value has several facets to it. The question of value is certainly important when examining art.

1.1. Intrinsic versus subjective. Because of the materials used in creating some works of art, there is intrinsic value. For example, Damien Hirst created an art work known as "For the Love of God". This piece of art includes diamonds, platinum, and human teeth. The intrinsic value refers to the cost of the materials used (Steinmetz, 2009). The subjective value would be determined by the degree of an individual's pleasure or displeasure in looking at and owning the art work (Subjective value, 2016).

The demand for valuable art works exhibits an inelastic price demand. In such circumstances, a greater percentage increase in price results in a lower percentage change in quantity demanded (Mandel 2009, 2013; Mankiw, 2015). If a famous artist passes away, we know the amount of his or her art works cannot grow. Thus supply would be perfectly inelastic. The people who may buy valuable art works constitute a share of the very rich individuals (Lo, 2013).

\subsection{Correlations between art prices and some} equity return on investments. Goetzmann et al (2011) used a long-term market index that had data, as far as the eighteenth century. Both lagged term equity markets' return on investment figures and same year equity markets' return on investment figures correlated in the way art prices changed. When the income inequality was pronounced this could lead to higher art prices. Indeed, there is a long-term relation between top incomes and art prices (Goetzmann, 2011). Mandel (2009, 2013) notes that an inelastic supply in the art market makes the demand for art "the only meaningful driver of investment returns". In fact, the price of an art object is only limited by how much collectors are willing and able to spend on that art object. So when there is a rise in buying power among art collectors, this may be expected to lead to higher art consumption, which brings higher price levels in the art market (Mandel, 2009).
1.3. Value of artwork during the Third Reich era. Art works stolen or "sold" under duress did not denote their true values. If there is no efficient market where buyers and sellers freely enter into transactions, we can say there is no true market. Therefore, the true value of these art works would have to be done via an accurate appraisal (Aalders et al., 2004; Ally, 2005; Boucher, 2015; Ronald, 2015).

\subsection{Using masterpiece art works as a type of} money during the Third Reich. One medium of exchange used by a very limited number of people, in Germany during the Nazi era, was art. To start with, some Jews were correct in seeing the Nazi era coming. They sometimes gave their masterpiece art works to the Nazis in exchange for safe passage to a non-Nazi country. Of course this was hardly a fair market, as the transactions were made under duress. The Nazi era lasted from 1933 to 1945. Some Nazis used art works as a means to purchase their way to another county, such as Paraguay, Argentina, and other countries willing to accept Nazis (Aalders et al., 2004; Ally, 2005; Boucher, 2015; Ronald, 2015).

\section{Examples of stolen art}

During the Nazi occupation, in the Netherlands, 8.5 million citizens suffered losses estimated at 3.6 billion Dutch guilders. Furthermore, approximately one-third of these losses were borne by Jews, even though they comprised a mere $1.6 \%$ of the country's population. In today's terms, the German Nazis took away assets from the Dutch Jews worth about $\$ 7$ billion. Often the threat of imprisonment or worse was used to make Jews give their assets up at extremely low prices. Giving a little money for a very valuable item made it look as if a trade was in effect happening. Yet commerce is always to be conducted without people being under duress (Aalders et al., 2004). A ploy to steal Jewish bank deposits was created using the ruse a fake branch of a respected Jewish-owned bank, named Lipmann, Rosenthal, and Company. Decades after World War II, many pre-war exhibits and other art works remained untraced" (Aalders et al., 2004; Ally, 2005; Ronald, 2015; Harris, 2016). In Third Reich Germany, property from Jewish people was often given to nonJewish citizens, in Germany, in order to keep them placated (Aalders et al., 2004). Now we will look at three specific examples of the journey of three different art works that came into contact with fascist thieves. Nazi thieves stole all types of art work. Yet, we selected three very famous paintings to analyze, as representative of stolen art work. In these three examples, the famous paintings came back to the rightful owner. Though not all these type paintings have been returned so far, as time goes by, hopefully more are. 
2.1. Matisse's "Seated Woman" (1921) NPR (2015). Ronald (2015) explains that Hidlebrand Gurlitt was one of the official art dealers for Hitler, Goering, and other Nazi leaders. NPR (2015) notes that Hildebrand entered inside of the abandoned homes of rich Jewish collectors and carried away their pictures. Giliberti (2001) points out that work camps created via the orders of such Nazis as Albert
Speer allowed for the confiscation of art that ended up in the collections of such individuals as Speer, with greater amounts going to such Nazi leaders as Herman Goring (Winter, 2013). A notable painting was Matisse's "Seated Woman" (1921). This masterpiece was one of many art works he acquired through theft, an art work eventually reunited to its rightful owners (NPR, 2015).

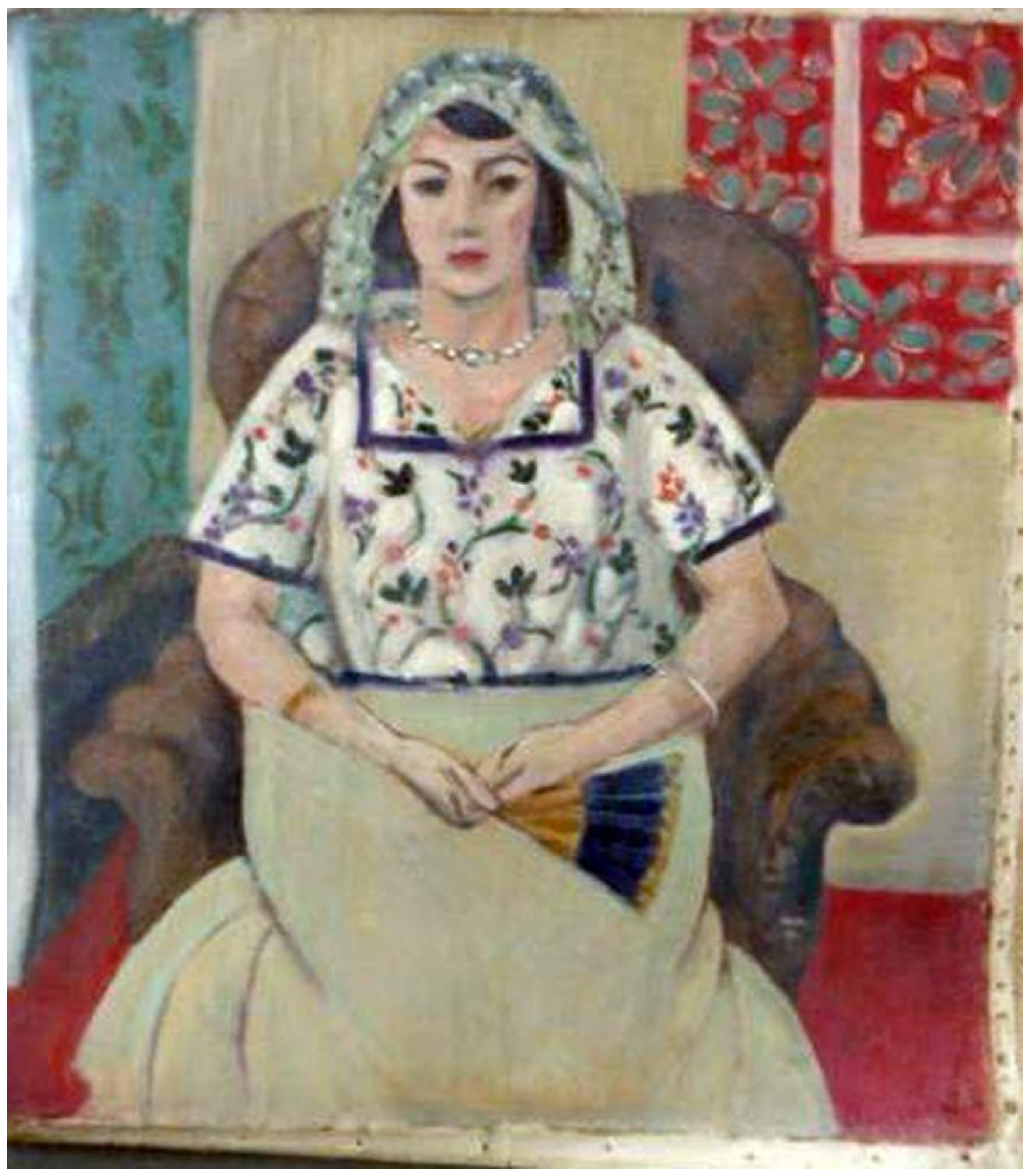

Figure 1. Matisse's "Seated Woman"

Source: Blair (2015).

2.2. El Greco's "Portrait of a Gentlemen". This painting was seized by the Gestapo in 1944. Julius Prester was an important industrialist, banker, and art collector who fled Vienna in March, 1938. That was when Germany annexed Austria. He tried to locate the painting after war. Furthermore, even his heirs kept trying, after Julius passed away. Then earlier in March 2015, an El Greco painting looted by the Nazis was returned to the heirs of its rightful owner (Boucher, 2015). 


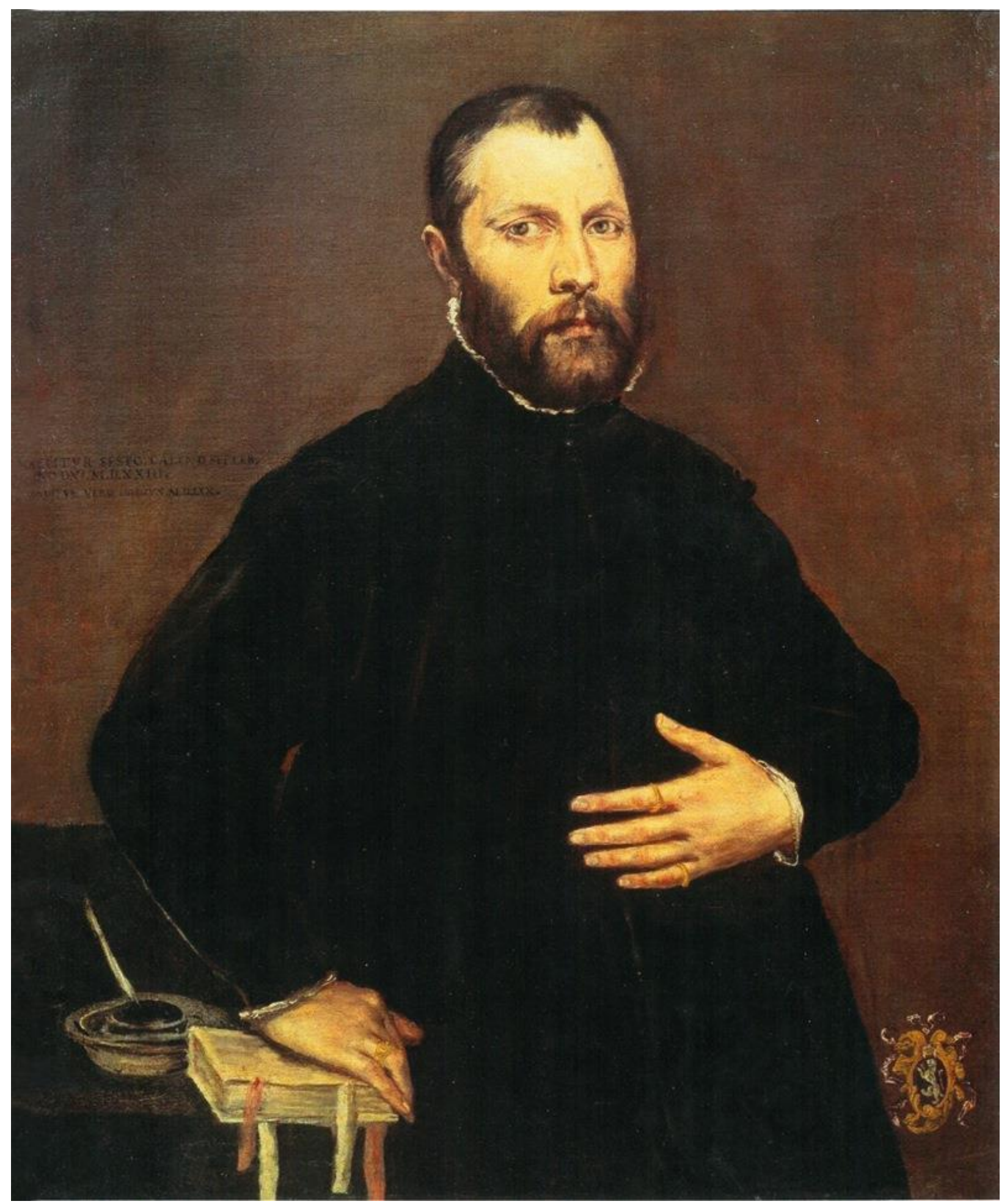

Figure 2. El Greco's “Portrait of a Gentlemen” (1600)

Source: Winer et al. (2015).

2.3. August Klimt's Portrait of Adele BlochBauer I. This painting is also called "The Lady in Gold" or "The Woman in Gold". This painting is by Klimt. It was completed between 1903 and 1907. This portrait of Adele was commissioned by her husband Ferdinand Bloch-Bauer. He was a Jewish banker and sugar producer. The painting was stolen by the Nazis in 1941 (Klimt, 2017).
The painting was displayed in a museum in Vienna, Austria. Finally, after years of effort, the Bloch-Bauer heirs were able to affect the return of the painting to the family. Later the painting was sold for $\$ 135$ million, which was a very high price for even masterpieces. This painting is "the final and most fully representative work of Klimt's golden phase" (Klimt, 2017). 


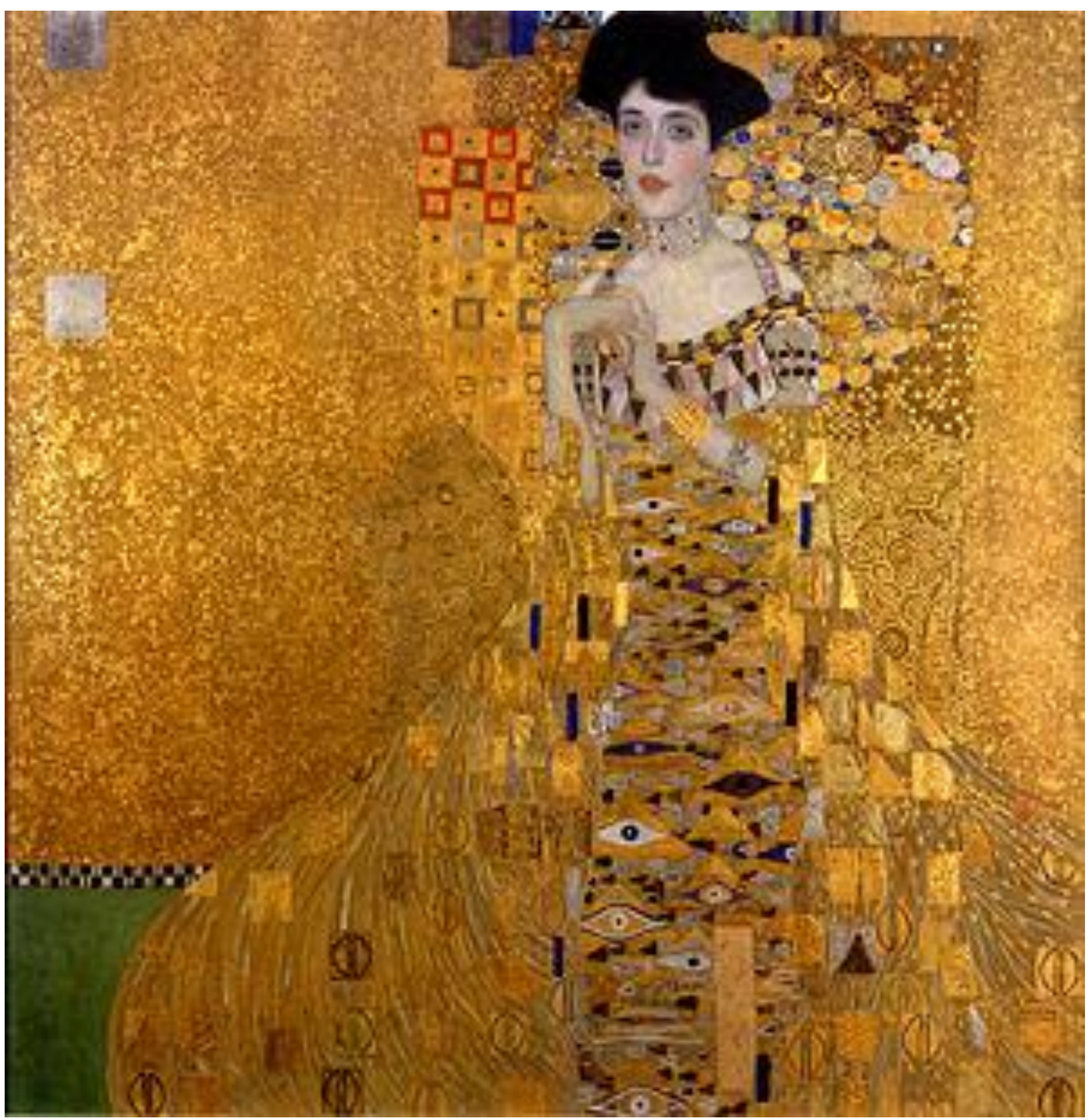

Figure 3. August Klimt's "Portrait of Adele Bloch-Bauer I"

Source: Cohen (2015).

\section{Conclusion}

The theft of art by the Nazis during their rule in Europe in the part of the 1930s and 1940s was tragic all around. Art works held value and the true owners were never adequately compensated by the fascists. Furthermore, since World War II ended, there have been efforts to retrieve these masterpieces. Some efforts have met with success. Notably, Harris (2016) describes some of this. One question that comes up is whether these art treasures should be considered money or not. Obviously, if they are sold in a fair market they will produce monetary compensation. However, in the economic sense, these art works are not really money. They are not used as a unit of account, which true money is used as. They are not a medi- um of exchange widely used among all people, another important trait of true money. However, they do in fact represent a store of value, which is another characteristic of money. Indeed, some art work may be a very good store of value. This value is subjective value, which is subject to the highest bidder, though these art works are seen to have a great value in general for art collectors. This important point about value is agreed upon by art collectors and economists.

Endnote: Paul Harris discussed, with Paul Gentle and Marco Giliberti, the use of art works in limited transactions during the Third Reich and its aftermath. In this article, Gentle and Giliberti looked at the idea of whether the art works could be termed money in the economic sense. 


\section{References}

1. Aalders, G., Pomerans A., \& Pomerans, E. (2004). Nazi Looting: The Plunder of Dutch Jewry During the Second World War. New York: Berg's Publishers.

2. Ally, G. (2005). Hitler's Beneficiaries: Plunder, Racial War, and the Nazi Welfare State. New York: Henry Holt and Company, Inc.

3. BBC News (2015). Dutch royal family to return Nazi looted art. Retrieved from http://www.bbc.com/news/entertainment-arts-32135127

4. Blair, E. (2015). Looted By The Nazis, Matisse's 'Seated Woman' Finally Finds Her Way Home. Retrieved from https://www.npr.org/sections/thetwo-way/2015/05/15/406999313/looted-by-the-nazis-matisses-seated-womanfinally-finds-her-way-home (November 29, 2017).

5. Boucher, B. (2015). El Greco stolen by Nazis and Sold by Knoedler Returns to Rightful owners. Artnet News. Retrieved from https://news.artnet.com/market/el-greco-nazis-loot-returned-280817 (March 24, 2017).

6. Cohen, P. (2015). The Story Behind 'Woman in Gold': Nazi Art Thieves and One Painting's Return. The New York Times. Retrieved from https://www.nytimes.com/2015/03/31/arts/design/the-story-behind-woman-in-goldnazi-art-thieves-and-one-paintings-return.html (November 29, 2017).

7. Gentle, P. F. (2016). Native American Wampum for Non-Monetary Uses and For Use as Money. Public and Municipal Finance, 3, 6-21.

8. Giliberti, M. (2001). Principi della citta nazista; l'immaginario autoreferenziale in Albert Speer. Istituto Universitario di Architettura di Venezia, Italia (Bachelor Thesis).

9. Goetzmann, W. N., Renneboog, L. \& Spaenjers', C. (2011). Art and Money. The American Economic Review, 101(3), 222-226.

10. Harris, Paul. (2016). Alabama Monuments Men. Alabama Heritage, 121, Summer, 10-21.

11. Hersokovits, Melville J. (1965). Economic Anthropology: The Economic Life of Primitive Peoples. New York: W.W. Norton, Incorporated.

12. Klimt (2017). Portrait of Adele Bloch-Bauer I. Retrieved from https://en.wikipedia.org/wiki/Portrait_of_Adele_Bloch-Bauer_I (June 29, 2017).

13. Lo, A. (2013). Supply and Demand of Rare Paintings, Prezi, January 27. Retrieved from https://prezi.com/_k9qdvwd3zjl/supply-and-demand-of-rare-paintings/

14. Mandel, Benjamin R. (2009). Art as an Investment and Conspicuous Consumption Good. American Economic Review, 99(4), 1653-1663.

15. Mandel, Benjamin, R. (2013). Investment in Visual Art: Evidence from International Transactions. In Victor A. Ginsburgh \& David Thorsby (Eds.), Handbook of Economics, Art of and Culture (vol. 2). Elsevier.

16. Mankiw, N. G. (2015). Principles of Economics. Stamford, CT: Cenage Publishers.

17. Melissa, Eddy, \& Alison Smale. (2016). Ruling Paves Way for Transfer of Art Trove Including Nazi-looted Works. New York Times, 12.

18. Mishkin, Frederic S. (2016). The Economics of Money, Banking, and Financial Markets. New York: Pearson Addison-Wesley.

19. NPR (2015). 1921 Matisse, Seated Woman, to be Reunited with Rosenberg Heirs. Retrieved from http://www.npr.org/2015/05/15/406938665/1921-matisse-seated-woman-to-be-reunited-with-rosenberg-heirs (May 15, 2017).

20. Radford, R. A. (1945). The Economic Organization of a P.O.W. Camp. Economica, 12(48), 189-201.

21. Ronald, S. (2015). Hitler's Art Thief: Hildebrand Gurlitt, the Nazis, and the Looting of Europe's Treasures. New York: St. Martin's Press.

22. Steinmetz, J. (2009). For the Love of God: The Artist as Capitalist. Retrieved from http://blog.art21.org/2009/04/29/for-the-love-of-god-the-artist-as-capitalist/\#.WEvpqMIzW3o (April 29, 2017).

23. Subjective Value (2016). Subjective Theory of Value. Retrieved from https://en.wikipedia.org/wiki/Subjective_theory_of_value (December 25, 2017).

24. Winer, S., \& AP. (2015). El Greco painting looted by Nazis returns to heirs. Retrieved from https://www.timesofisrael.com/el-greco-painting-looted-by-nazis-returns-to-heirs/ (November 29, 2017).

25. Winter, S. (2013). Hitler's Wristwatch: A Nazi Legacy Hidden in German Museum, Spiegel On-Line. Retrieved from http://www.spiegel.de/international/germany/germany-s-unsatisfactory-approach-to-art-looted-by-the-nazisa-880363.html (January 30, 2017). 